\title{
REAL ESTATE MASS APPRAISAL IN SELECTED COUNTRIES - FUNCTIONING SYSTEMS AND PROPOSED SOLUTIONS ${ }^{1}$
}

\author{
Anna Barańska, D.Sc., Ph.D. \\ Faculty of Mining Surveying and Environmental Engineering \\ AGH University of Science and Technology \\ e-mail:abaran@agh.edu.pl
}

\begin{abstract}
In this paper, the systems of real estate mass appraisal in some selected European countries will be discussed, in comparison with those of individual countries on other continents, in terms of similarities and differences in law, institutional scope and subjects responsible for its execution. With selected countries serving as an example, the practical aspects of operating the real estate owners' taxation system will be discussed as well the data acquiring process, considered price-making factors, proceeding methodology and circumstances taken into account in real estate cadastral valuation, giving consideration to national specificity.
\end{abstract}

Keywords: mass appraisal, modeling, real estate taxation.

\section{JEL Classification: R52.}

Citation: Barańska A. (2013), "Real estate mass appraisal in selected countries - functioning systems and proposed solutions", Real Estate Management and Valuation, vol. 21, no. 3, pp. 35-42.

DOI: 10.2478/remav-2013-0024.

\section{Introduction}

The mass appraisal of real estate is a much discussed problem in many European countries and others worldwide. As can be expected, it arouses controversy of a different kind in the societies of these countries. Although the procedures used in different countries are varied, some common trends can be observed. They may be used for arranging the real estate appraisal process for mass appraisal. Such procedures are formulated, for instance, during seminars or international conferences.

One of the biggest organizations for people professionally involved in real estate appraisal and taxation is the "International Association of Assessing Officers - IAAO", aimed at promoting innovation (scientific research) and good practice, as well as providing education on assessing real estate and the taxation policy.

IAAO, in its standards concerning mass appraisal (IAAO 2012), states that, among others:

- Mass appraisal requires complete and accurate data, effective valuation models, and the proper management of resources.

- A successful data collection program requires clear and standard coding, careful monitoring and the introduction of a quality control program. A physical inspection of real estate is necessary to obtain initial data regarding property characteristics.

- The modeling of a real estate market for mass appraisal must be preceded by a detailed analysis of the local real estate market.

\footnotetext{
1 The task was carried out within the scope of statutory research in the Department of Geomatics, Faculty of Mining Surveying and Environmental Engineering, AGH Krakow, Poland
} 
- All three approaches to value - the cost approach, the sales comparison approach, and the income approach - are useful for mass appraisal.

- The cost approach is applicable to all building plots and, if used properly, can produce highly accurate valuations.

- State or local laws may require the value of a building plot to be separated into land value and the value of its components.

- Land values should be reviewed annually. The properties should be physically inspected and revalued at least once every four to six years.

- The use of two or more approaches for a given type of property should produce greater accuracy.

\section{Real estate taxation systems ${ }^{2}$}

In European Union countries, the most dominant system is, by far, a value system of real estate taxation (ad valorem). The natural system (based mainly on real estate countable area) is valid in only four EU countries (i.e., The Czech Republic, Poland, Slovakia and Hungary). Within the valuation categories of the market systems, the proportions of the number of EU countries using particular constructions of real estate taxation are similar. The most common is a taxation base based on value close to the market value, but historical value and real value are almost equally popular.

Within the categories of non-market valuation systems, the situation is quite different. None of these types of real estate taxation methods are fully represented in any of the examined countries; they are used only in a few new EU member countries where the area taxation system or the system of value close to the market value dominate and play a supplementary role in relation to the principal system.

In the remaining countries of the world, the situation is comparable to that of EU countries because valuation systems are unquestionably the most common. Only four countries apply the natural surface systems, i.e.: China, India, Israel and Russia. The most common solution to real estate taxation in the remaining countries is that of real value. Such a taxation base is dominant in the USA, Canada, Australia and Japan. Value close to that of market value is used much less often and no historical systems are found.

\section{Mass appraisal in selected countries - particular cases}

In this section, the formal and legal framework of mass appraisal systems functioning in selected European countries as well as in the United States and Canada will be presented.

The cases of the individual countries described in this article have been developed, among others, based on reports presented during the "International Workshop on Mass Appraisal" seminar, organized by Commission No 9 on the Appraisal and Administration of Real Estate of FIG (International Federation of Surveyors), in Paphos on Cyprus, in September 2012.

\subsection{United States and Canada ${ }^{3}$}

Both countries in North America have a common feature - a very limited role of central state authorities. Every state in the USA and every province in Canada have their own law. Authorizing the use of given software in real estate appraisal is regulated by state authorities. In both countries, there are professional qualification requirements of persons performing the appraisals.

In the United States, with the exception of the states of Montana and Maryland, the scope of appraisals on behalf of the central government is limited and they can be carried out only for roads and public properties; in Hawaii, the central government is not empowered to assess properties, while in Canada, the central authority can assess properties but only in cooperation with the authorities of a given province.

In the USA, 37 out of a total of 50 states follow a transparent pricing policy in relation to the sale of real estate, whereas in Canada, all provinces follow an open policy. Both in the USA and Canada, cyclic (every 1-6 years) real estate appraisals are legally required and used in practice for taxation purposes. There is also local supervision of the appraisal results, including the possibility of requiring another appraisal of the real estate value. The measures of real estate value levels in the separate

\footnotetext{
${ }^{2}$ HOPFER (2008).

${ }^{3}$ DORNFEST (2012).
} 
layers of real estate types and locations are the median, and weighted mean or arithmetic mean, allowing for a deviation of a few percent.

\subsection{Northern Ireland ${ }^{4}$}

Northern Ireland, a member of the European Union since 1973, where domestic evaluation was completed in 2007 involving the valuation of approximately 680,000 residential properties, will be presented as the first of the European countries.

Information gathered on the real estate mass appraisal system used in this country has been presented below:

- The domestic evaluation was completed in 2007, involving the valuation of approximately 680,000 residential properties. All owners were notified about the current values of their properties and the mass appraisal itself was preceded by an extensive informative action run by the media. This revaluation was based on capital value and represented a significant reform from previous valuations based on annual rental value. Commercial properties, revaluated separately every five years, are still based on rental values.

- A Sales Inspection Database (SID) was set-up for the purpose of recording domestic sales information, e.g., sale price, sale date, newly-built/2nd-hand sale, etc. SID was linked to the main database, which allowed the physical characteristics of each sold property to be recorded. This formed the basis of a comprehensive program of controlling the transactions.

- The Valuation and Lands Agency (VLA) established a CAMA (Computer Assisted Mass Appraisal) modeling team, the core task of which is data preparation. The activity of this team enabled big errors from the SID database, which was never before used for modeling purposes, to be detected and eliminated; it was estimated that approximately $20 \%$ of information in the geo-database, was either missing or incorrect.

- For modeling the real estate market, NI was divided into 25 geographical regions, each of which was determined by its own number of neighborhoods (NBHDs). Exponential multiplicative models for continuous variables, with coefficients corresponding to binary variables, were the most reliable; beta weights of regression models were used to determine the weights of individual physical and geographic characteristics, indispensable for assessing similarity between properties.

- Since people were properly prepared, the whole process of mass appraisal was met with general approval.

The following lessons can be drawn from the mass appraisal carried out in Northern Ireland:

- It is necessary to prepare a reliable database before modeling the real estate market.

- It is possible to build a reliable model of "neighborhoods" based on geospatial data but these "neighborhoods" should be based on the market knowledge of appraisers and thus free of any restrictions related to external data sources.

- In rapidly changing markets, the analysis of data can be enhanced through the knowledge of unit values in preliminary time or knowledge regarding the trends of the sales ratio.

- "Beacons" (appraisals of particular properties made by qualified valuers) can effectively supplement sales data concerning selected types of properties.

- Appraisal models which use multiplicative form and take into account logarithmic functions are an effective and efficient technique of mass appraisal.

- A positive social attitude is essential, especially when performing a revaluation of real estate. A good campaign can be considerably helpful in winning public acceptation and can reduce the number of formal appeals.

\subsection{Slovenia ${ }^{5}$}

In Slovenia (in the EU since 1 May 2004), the Mass Valuation System (MVS) is used as a multipurpose system to support not only the property taxation system, but also other public and local needs and tasks required by the Act on Mass Appraisal. In 2009, the so called Valuation Office, part of the Chamber of Geodesy and Cartography and subordinate to the Ministry of Infrastructure and Space, presented the applied model and the results of adapting it in municipalities within a mass appraisal

${ }^{4}$ MCCLUSKEY (2012)

${ }^{5}$ Mitrovic (2012). 
process. The implementation of the system and setting up a real estate register took place from 2006 to 2010. In 2010, a mass appraisal was carried out. Property owners were informed about the trial value determination of their properties and real estate data used for that purpose. The final proposal of the valuation was prepared based on a study of the property owners' complains about the trial value determination and according to mass valuation standards. The mass valuation system in Slovenia was fully developed and implemented in January 2012.

The Government of the Republic of Slovenia passed regulations on defining the 21 valuation models based on the final proposal. This was the final step of the implementation phase. The number of models results from three appraisal approaches. Each of them was applied to a different type of real estate: the comparison approach for 9 types of real estate (i.a., dwelling properties, agricultural lands and forests), the income approach for 5 types of real estate (i.a., for agricultural lands, mines, and gas stations), and the cost approach for 7 types of real estate (i.a., farm buildings, public buildings, vineyards, and industrial buildings).

As the models applied in mass appraisal are complicated in form, the predictions obtained using them were presented as value tables (information on the size and age of a piece of real estate: dates of construction, roof repair, window change, elevation renewal, installation change) and as so called point tables, describing the quality of the real estate and some special circumstances that relate to what is referred to as zones (reflecting the location of property).

Presently, mass appraisal in Slovenia is fully formalized and implemented. Since January 2012, all registered properties (about 6.5 million entries) had legally binding determined market values as of 1 July 2010. By the end of 2012, the indexation of all groups of properties was completed. If an index exceeds $10 \%$, the value is revaluated. Values relevant on 1 July 2012 were determined in this way for all registered properties.

The Surveying and Mapping Authority of Slovenia holds complete responsibility for the implementation and maintenance of the MVS in Slovenia. To increase the efficiency of the agency, the Valuation Office has appointed a group of 24 experts from the fields of geodesy, economics, construction and informatics at the state, central and regional level. The main tasks at the central level (12 experts) are:

- development and calibration of valuation models,

- development of valuation and indexation procedures,

- development of methodology for using data and information by various public users,

- preparation of valuation regulations and cooperation with ministries and municipalities,

- IT development,

- calculation of property market values for all properties in the real property data base,

- central analysis of the real estate market and quarterly, half year and annual reports on the property market.

The main tasks at the local level (12 experts in 6 regional locations) are:

- review and improvement of sales and rent contracts,

- regional analyses of the property market and preparation of regional property market reports,

- cooperation with municipalities (210 of them),

- adjustment of valuation models to local conditions within the framework of cooperation with the managements of municipalities,

- monitoring (overview) of sale and rent transactions of industrial, commercial, office and agricultural real estate,

- cooperation with the taxation authority and social offices at the regional level.

The Valuation Office responsible for the operation of the MVS system collects two types of data, i.e., market and descriptive data. The main source of real estate market data is a register of sale prices, including all transactions since 2007, as well as rental data gathered from natural and legal persons, whereas data concerning the actual real estate are taken from a real estate register set up in 2008, based on a land register, land cadastral survey, and building cadaster. The register of sale prices is held by the Taxation Office in electronic form. Every transaction is checked manually by inspection of the sales contract or by personal observation of the property.

The real estate register is constantly updated. Any changes in the land register or cadaster, as well as or those declared by the property owners on appropriate questionnaires, are already visible in the real estate register the next day. This calls for correspondingly immediate possible correction of property value. In the case of the market data register - updating is performed every month, as 
transactions made during a given month are registered the next. At least every 4 years, it is legally required to verify the appraisal models. In the meantime, real estate values are determined using the indexation method.

There is still no political will to make full use of the implemented mass appraisal system for taxation purposes. Today, property tax consists of two taxes, one for the state and the other for the local level budget. Both taxes are based on administrative methods of calculation and do not represent the real market value of a property. However, the MVS is integrated with the operation of legal acts concerning the following: mortgages, social subsidies, the property transformation tax, the tax on inheritance and donations, and the capital gains tax arising from changes in land use. Private experts, investors, banks, real estate agencies, insurance agencies, municipal administrations, etc. have shown an interest in the results of MVS operations.

Considering the political resistance, the Valuation Office tried to meet the following conditions during the development stage of the MVS for its implementation:

- registration and maintenance of necessary data and information on all properties in the country in a digital data base,

- definition of property value as market value,

- development of valuation models to calculate the value of all properties registered in the Real Property Data Base (RPDB),

- development of an effective indexation method for the value of properties in the RPDB database,

- providing simple public access to property data, sales data and property market values to assure transparency of the property market.

\subsection{Lithuania ${ }^{6}$}

In Lithuania, which similarly to Slovenia and Poland hasbeen a member of the EU since 1 May 2004, the implementation of a mass appraisal system was commenced and the first mass appraisal of land was performed in 2002. The market value based tax on buildings and constructions was introduced in 2006, with the land market value based tax introduced on 1 January 2013. The separation of these two taxes is historically justified, since at the beginning of the 90s, the tax system in Lithuania already distinguished a property tax for land and for buildings.

Since 1 January 2013, the new law has provided for the taxable value of land to be the average market value of the land estimated by the sales comparison approach using mass appraisal. According to the law, tax rates range from $0.01 \%$ to $4 \%$ (abandoned land can be taxed at the highest rate). Previously, the land property tax was calculated on the basis of the so called normative land value (from $0.5 \%$ for agricultural land to $1.5 \%$ for land zoned for construction, excluding forests). Tax rates are decided annually by municipalities and tax revenue is levied to their budgets.

In some cases, replacement value adjusted with location coefficients is used as the base for taxation instead of market value. Properties used for commerce shall be valued in a mass valuation process using a sales comparison approach and income approach (capitalisation techniques or discounted cash flow techniques). In the case of properties used for residential purposes, such as gardens and garages (with the exception of industrial garages), the sales comparison approach is used in mass valuation. Engineering structures are assessed by the cost approach (by calculating the percentage of physical deterioration). For other properties, the cost approach with the percentage of physical deterioration and the location of the adjustment coefficient is applied.

The law also provides that the taxable value of immovable property may be that of the value estimated by applying single property valuation; however, this approach is only used in the case of an appeal. An appeal against an estimated value is considered justified when the difference between the value determined in mass appraisal and the value determined individually exceeds $20 \%$.

The institution engaged in mass appraisal is the State Enterprise Center of Registers, and within it - the Department of Valuation for Public Needs, employing 40 certified appraisers and market analysts. This Enterprise also receives appeals against the appraisal results. The initial review of mass appraisal results is performed by the local authorities who establish the tax rates.

\footnotetext{
${ }^{6}$ ALEKSIENE (2012)
} 
Every year, all properties are appraised within the mass appraisal, irrespective of whether they are taxable or not; buildings and land are appraised separately. In general, collecting data for the mass appraisal is not a task of property experts. Every property must be measured by a certified surveyor, representing, as a rule, a private firm. Data gathered in this way are introduced into the real estate database in a uniform digital form and constitute the basis for developing an automated appraisal model based on statistical methods. Real estate transactional data, along with a copy of the sales contract, are passed to the Center of Registers within 24 hours of the transaction via the Internet. The availability of a digital database covering the physical and legal characteristics of a given property and up-to-date market information allow for the application of the CAMA system. The increasing use of statistical methods for the selection and processing of data reduces the likeliness of mistakes and random factors affecting the value.

Currently, there are more than 6 million property units registered in the Real Property Data Base, more than 2 million of which are land parcels. Within one year, more than 100,000 real property transactions are concluded and end up in the same database, providing a basis for market analyses and mass valuation.

Mass appraisal activities are planned every year. Over 10 years of practice, the following workflow has been established:

1) review of outcomes of previous mass appraisals, zoning verification (the same zones for land and buildings) depending on the price distribution in space and time adjustment if sales data exceed 1 year periods - 3-4 months,

2) models specifying and calibrating the use of statistical analyses methods $-4-5$ months,

3) evaluation of mass appraisal performance, correction of models -2 months,

4) preparation, discussion and approval of mass appraisal documents -3 months.

Land and building appraisal data is made public and freely available to all users. The website of the Center of Registers provides free access, with the protection of personal data. The law specifies that the taxable values are valid for no longer than 5 years. It also provides for taxpayers to be able to appeal the taxable value during the $1^{\text {st }}$ quarter of each year. In 2011, when the new taxable values came into force, 247 appeals, regarding the taxable value of approximately 380 real property objects, were submitted.

\subsection{Greece $^{7}$}

A contrasting example to those previously discussed is Greece (a member of the EU since 1981), where a transparent system of real estate taxation based on property value established by mass appraisal is still far from being implemented. Below are some features describing the current situation in this country:

- There is no operational Computer Assisted Mass Appraisal.

- Property sales data is not public; even when a Bank is financing a loan, it possesses knowledge of only the valuation.

- Approximately 40 different taxes are currently imposed on real estate properties.

- The basis for residential appraisals is usually the market value and, for certain detached residences, depreciated replacement cost.

- Since market values are not known or registered, the basis for real estate taxation, professional fees, expropriations, etc. is the "objective" value. The tax on real estate transactions is imposed based on whichever value is higher - the "objective value" or "transaction price".

- The "System of Real Estate Values Objective Calculation" started operating in 1985 and now covers the whole country, the residential areas of which are divided into neighborhoods (zones). A base value is assigned to each neighborhood by a committee of officials from the Ministry of Economics. This value corresponds to the value of one square meter of a new $1^{\text {st }}$ floor apartment. Various simple coefficients (floor, age, etc.) produce the final value which does not simulate the market in any way.

- The objective value should be updated every 2 years but was last updated on 01.03.2007.

- The "Real estate appraiser" specialty is not a recognised profession (no legal framework and no legal fees, no specific code of ethics, no taxes on income from carrying out an appraisal, and no Valuation Chamber). There is a Hellenic Appraisal Institute which conducts mainly educational

\footnotetext{
7 LABROPOULOS (2012).
} 
activities as well as a Society of Greek Experts, that is an association of people appraising the properties.

- According to the Bank of Greece Governor's Act, the monthly submission of selected data from all valuations carried out by MFIs (Monetary Financial Institutions) has been compulsory in Greece since 2008; In 2011, a law was passed providing free access to data of all public sector institutions and to the geodata portal, which is currently in development. Cadastral data on real estate are accessible only in some regions and usually concern residential proprieties; construction data were registered only during the stage of the pilot implementation of the data collection project and they have not been updated since 1995.

- There is a concept to use all the data on appraised properties to build a model which would then be used to appraise all the properties within a geographic region as well as to apply statistical analysis methods to select essential features among all determinable property features; within the appraisal methodology, the application of neighborhood analysis and regression analysis with the use of LSM (Polish MNK) and spatial statistics has been proposed.

- The following are proposed within the publication of appraisal results: unlimited accessibility of tax information, registered access to the average values of a determined type of real estate for experts, notaries, lawyers, real estate office agents and engineers in addition to controlled access to monthly appraisal reports, as well as the availability of specific real estate data for banks, certified appraisers and insurance firms.

\section{Summary and conclusions}

As can be seen, there is still a lot to do on the matter of creating a transparent and efficient system of real estate mass appraisal in Greece. It seems that Greece is considerably further from achieving this than Poland, where the subject of the real estate mass appraisal was already undertaken in 1997 by the Act on Real Estate Management. Eight years after the Act on Real Estate Management was passed by the Polish parliament, in 2005, the Polish government issued an Ordinance on the Mass Appraisal of Property. This ordinance, though relatively short, explains the technique of executing a property mass appraisal in Poland in detail, determines the property features to be considered in the estimation process for cadastral purposes and points out the sources that should be used for data collection.

An undoubted drawback of the above mentioned ordinance, as noticed by Polish researchers, is the separation of developed properties - the land from its components, according to the following paragraphs: $\S 2, \S 10, \S 11$ and $\$ 13$. As cadastral value should relate to property market value (art.161, item 2 of the Act on real estate management) - estimating the values of the land and buildings on this land separately creates additional difficulty in the process of verifying the cadastral value that should be compared with the market prices or with the market value (\$15, item 2 of the ordinance Market value is, of course, the most probable price achievable in free trade turnover. It often derives directly from the prices of sold properties. At the same time, it is well known that when selling a built-up property, the price of the whole property is established without differentiating between the land and man-made objects permanently connected with it. A final executive ordinance, still expected in Poland, should correct this ill-considered regulation of the ordinance of 2005.

Considering the fact that, 7 years after the publication of the Ordinance on the Mass Appraisal of Property, an executive legal act (mentioned in art.163 of the Act) still does not exist, the process of determining the cadastral value has not yet begun in practice. This is conditioned exclusively by the policy because, essentially, those constituting the potential executive committee of property appraisal in Poland are well prepared. The existing legal acts (act and ordinance) determine the conditions needed for performing the mass appraisal (except the execution date and sources for funding the whole process) and scientific teams have developed a number of analytical algorithms with potential.

Based on the above examples and on broader analyses, the results of which are contained in the reference (Hopfer 2008), the following observations were made:

- value systems are characteristic of capitalist countries while surface systems - of former socialist countries,

- market value systems, in contrast with area systems, are homogeneous structures, with the exception of particular solutions for some objects of taxation, such as offices or flood banks,

- non-market value systems generally supplement other systems of real estate taxation including business taxation, 
- within the value systems, it is characteristic for most market solutions, i.e., real value, to be taken on by the most developed countries: USA, Canada, Australia, Japan, Hong Kong, Denmark, Holland, Sweden, United Kingdom or Spain; there is a similar relationship in the case of natural bases; the market base is more typical of developed countries, especially the countable area,

- historical systems are typical of only European Union countries, especially those of the "Old" European Union, as they exist only there.

According to this economical division of countries, it can be indicated that both in EU countries and worldwide, the situation in regard to using value as the real estate taxation base is not uniform. In certain countries, the systems of capital or rent value are valid in principle and in some of them, mixed systems are in use. The best examples are countries in the United Kingdom as well as Germany and Switzerland, although to a lesser extent; depending on the type and purpose of real estate, they use both capital as well as rent value. However, it must be stressed that rent value systems are rare in the examined countries. More than half of the examined countries connected the real estate taxation system with capital value.

\section{Bibliography}

ADAMCZEWSKI Z., 2011, Elementy modelowania matematycznego wwycenie nieruchomości, Podejście porównawcze, Oficyna Wydawnicza Politechniki Warszawskiej, Warszawa.

ALEKSIENE A. BAGDONAVICIUS A., 2012, Mass appraisal system in Lithuania, International Workshop on Mass Appraisals, Pafos, Cyprus, 14-16 September 2012.

BARAŃSKA A., 2012, Mass Appraisal of Real Estate in Poland - legal basis and practice implementation, INTERNATIONAL WORKSHOP ON MASS APPRAISALS, PAFOS, CYPRUS, 14-16 SEPTEMBER 2012.

DORNFEST A.S., 2012, Mass appraisal practices in the United States and Canada, International Workshop on Mass Appraisals, Pafos, Cyprus, 14-16 September 2012.

Dornfest A.S., VAN SANT S., ANDERSON R., BROWN R., 2010, State and Provincial Property Tax Policies and Administrative Practices (PTAPP): Compilation and Report, Journal of Property Tax Assessment \& Administration, Volume 7, Issue 4, paper on the website: http://www.iaao.org/uploads/PTAPP_2010.pdf.

HOPFER A., 2008, Metody masowej wyceny, Studia Podyplomowe na Wydziale Prawa i Administracji Uniwersytetu Warszawskiego, Warszawa, paper on the website: http://www2.wpia.uw.edu.pl/files//mszalata/Hopfer\%20METODY\%20MASOWEJ\%20WYCEN Y\%20cz.\%20I.pdf.

IAAO International Association of Assessing Officers, 2012, Ratio Study Practices in the United States and Canada: Results of 2011 Survey, The Technical Standards Committee, IAAO, Journal of Property Tax Assessment \& Administration, Volume 9, Issue 1.

IAAO International Association of Assessing Officers, 2012, Standard on Mass Appraisal of Real Property, Kansas City, Missouri, USA.

LABROPOULOS T., 2012, Towards an integrated GISECAMA system for residential property taxation in Greece, International Workshop on Mass Appraisals, Pafos, Cyprus, 14-16 September 2012.

MCCluSkey W., MONTGOMERY E., WOODS N., BRONTE A., 2012, Domestic Revaluation in Northern Ireland: A Review, INTERNATIONAL WORKSHOP ON MASS APPRAISALS, PAFOS, CYPRUS, 14-16 SEPTEMBER 2012.

Mitrovic D., 2012, Multipurpose use of mass appraisal system in Slovenia, International Workshop on Mass Appraisals, Pafos, Cyprus, 14-16 September 2012.

\section{legal acts:}

Rozporządzenie Rady Ministrów z dnia 29 czerwca 2005 r. w sprawie powszechnej taksacji nieruchomości (Dziennik Ustaw nr 131, pozycja 1092).

Ustawa z dnia 21 sierpnia 1997 r. o gospodarce nieruchomościami (with later changes) (Dziennik Ustaw nr 115, pozycja 741).

web sites:

www.iaao.org. 